\title{
EVALUATION OF MULTIPLE RETAILERS' MARKET POSITIONS ON THE BASIS OF IMAGE ATTRIBUTES MEASUREMENT
}

\author{
Sigitas Urbonavičius ${ }^{1}$, Robertas Ivanauskas ${ }^{2}$ \\ Faculty of Economics of Vilnius University, Sauletekio al. 9, LT-10222 Vilnius, Lithuania \\ ${ }^{1}$ E-mail: sigitas.urbonavicius@ef.vu.lt \\ ${ }^{2}$ E-mail: robiv@yahoo.com \\ Received 0310 2005; accepted 08112005
}

\begin{abstract}
Intense competition in retailing sector requires searching for new and more effective tools of competing with rivals. One of the possible ways seems to go through applying positioning concept in retailing. Positioning in retailing refers to strategy for development of a desirable image, which would help to differentiate a retail company and move away from direct price competition. Besides that, image management provides possibilities for increasing customer perceived value and/or increasing prices. The paper presents methodology for establishing multiple retailers' positions. This methodology is based on evaluation of image attributes' importance for customers. Factor analysis allows revealing more general latent factors that are used to evaluate retailers' positions in a perceptual space. This allows drawing conclusions on how much Lithuanian multiple retailers are similar or differentiated from the standpoint of their customers.
\end{abstract}

Keywords: Positioning, position, image, image attribute, latent factor, multiple retailer, differentiation, perception space.

\section{Introduction}

During past decades, retailing sector was rapidly developing in many European countries. Retail companies, and especially multiple retailers (also called chain stores or multiple chains) started playing a very important role in distribution channels of many products. Multiple retailers took over some traditional functions of wholesalers. They also become a "VIP client" for many manufacturers, since they sell the major part of manufacturers' products. In many cases, relationship between multiple retailers and manufacturing companies become very close. Sometimes multiple retailers even take control over them, especially when place large orders for manufacturing private label (also called store label, private brand) products.

On the other hand, multiple retailers expand their influences towards their customers - final consumers. Managing large chains of stores they have contact with numerous buyers and can collect extensive information about their characteristics, behaviors and preferences. Starting from this, they can modify offered assortments and to some extent shape demand. Throughout these activities, multiple retailers themselves have become brands, which are equal to or even stronger than brands of manufacturing companies.

Competition in retailing sector forces to look for new and more effective competitive strategies. One of possible directions is related with applying traditional positioning concept in retailing sector. Careful positioning of already strong retailer's brands might open new competitive opportunities, and allow avoiding just price-based competition. It also can help differentiating retailer's offering from its rivals and occupying clear and consistent market niche, thus decreasing overall competitive pressure.

The positioning concept was developed from the standpoint of manufacturers ant their products (Ries, Trout, 1986). Later on, the concept showed its applicability in marketing services and all kinds of less tangible offerings (ideas, events, destinations). However, in retailing sector positioning ideas are not often used in a systematic way. The development of this idea was started just in the end of 20th century, 
and currently is just in the very initial steps of its analysis and applications.

The issue of positioning in retailing sector has not been scientifically researched in Lithuania yet and this paper is one of the first steps in this direction. The paper uses findings and methodologies of research in other countries, and also develops methodology of multiple retailer position evaluation. The main theoretical and methodological contribution is related with analysis of image attributes of multiple retailers and use of factor analysis in defining positions of chain stores in a perceptual space (perceptual map).

The objective of this paper is to evaluate market positions of multiple retailers, using the results of analysis of their image attributes importance for customers. The research is concentrated and limited to analysis of non-specialized multiple retailers that operate in Lithuania (further in the text they are called multiple retailers or chain stores).

Empirical findings of the paper allow understanding customers' attitudes towards importance of multiple retailers' image attributes and evaluation of stores. Besides that, empirical findings enable understanding multiple retailers' positions in customers' perception space. These issues are analyzed in separate paragraphs. Before them, we review findings of previous research and explain methodology of current research.

\section{Positioning concept in retailing and image research}

Retailing activities have strong specifics, which make them different both from manufacturing companies and service providers. Nevertheless, positioning concept starts to be considered a central concept of the competitive strategy of a retail company (Birtwistle, Clarke, Freathy, 1998). More specifically, positioning in retailing is defined as a strategy for development of image of a retail company (Berman, Evans, 2001). Through positioning, a retail company differentiates from its competitors and reveals its strengths and advantages. In case of clearer and more significant differentiation, buyers are less willing to switch to other retailers as substitutes. Based on this, a retailer is able to move away from head-to-head price competition. As a result, successful differentiation can lead to a relaxation of competition and higher retail margins (Bell, 2002). It is also important that differentiation enables not only to defend, but also to increase market share of a retail company (Rudolph, Becker, 2002).
Development of clear positioning strategy allows selecting proper and adequate marketing tools for attracting target segment customers and ensuring their loyalty to a retail company (Darling, 2001; Fernie, Fernie, Moore, 2003). Positioning enables a retail company to occupy specific market niche and decrease direct pressure of competitors.

However, position that is achieved through development of retail company image usually is not constant. It changes according to shifts in retail company's services, and according changes in positioning strategies of rivals. Therefore not only image development, but also it's monitoring and corrections are important in practical implementation of positioning concept.

Image in retailing refers to how a retail company is perceived by customers and other stakeholders (e.g. partners, suppliers, other members of a distribution channel). In other words, image is an overall impression about a retail company as it is perceived by customers and stakeholders. Image is a combination of retailer's functional qualities (or tangible, physical, practical attributes) and psychological attributes (or intangible, symbolic, emotional attributes) (Thompson, Chen, 1998; Sit, Merrilees, Birch, 2003; Sheinin, Wagner, 2003; Bloemer, De Ruyter, 1998). Some authors argue that physical characteristics dominate in image perceptions, because they directly facilitate the accomplishment of shopping tasks (Uusitalo, 2001).

Image is the basis for a retail company differentiation. It not only distinguishes a retail company from competitors, but also provides the basis for competitive advantage (Omar, 1999; Samli, 1998; Sullivan, Adcock, 2002). For buyers, image of a retail company is an important component both in a retailer choice and in a retailer patronage decisions (Newman, Cullen, 2001; Joyce, Lambert, 1996). Therefore analysis of positions allows comparing how different (or similar) competing retail companies or stores are.

Image plays an important role in customer perceived value concept (Kotler, 2003). This concept presumes that in selecting products or services customers evaluate perceived value of several alternatives. Customer perceived value is understood as a difference between total customer value and total customer costs. Image value is a component of total customer value, and can contribute to increase of this value. Therefore better image enables increasing probability that customer will select this product of service, if other components (product value, services value, personnel value and costs for customer) remain constant. Also, a retailer can simultaneously improve its image and 
increase prices (monetary costs for a customer), and customer perceived value remains stable. In general, image management opens opportunities for manipulating customer value and costs according to goals and objectives of a retailer.

Numerous retailer image studies are presented in scientific publications. Researchers have analyzed images of grocery stores (Uusitalo, 2001), more specialized sectors of fashion or apparel, footwear retailing (Birtwistle, Clarke, Freathy, 1998; Thompson, Chen, 1998; Porter, Claycomb, 1997; Garton, 1995), malls (Taylor, Cosenza, 2002), department stores (McGoldrick, Ho, 1992), shopping centers (Sit, Merrilees, Birch, 2003; Dennis, Murphy, Marsland, Cockett, Patel, 2002; Ruiz. 1999). Majority of studies analyzed importance of image attributes for customers in different retail sectors or for different store types, almost never concentrating on analysis of images of multiple retailers. Results of studies showed that importance of image attributes differ in different retail sectors and that it also depends on store type, product type, customer characteristics, study time and many more other factors (Mitchell, Kiral, 1998; Joyce, Lambert, 1996; Mitchel, 1998). Therefore it automatically suggests importance and need of a deeper research analyzing importance of image attributes.

\section{Research methodology}

Use of positioning concept in retailing is not comprehensively analyzed and not yet fully understood. This paper tries to contribute to better understanding of this issue.

The research is directed to analyze positions of multiple retailers that operate in Lithuania. For this, we first evaluate image attributes and their importance for clients of multiple retailers.

Multiple retailers operating in Lithuania and selling food products and various non-food items in this case seems to be a suitable research object. They were rapidly developing, and competition among them is rather intense. Majority of Lithuanian population frequently shop in chain stores, and therefore respondents may have rather strong opinions about characteristics of chain stores. This is specifically important for evaluation of multiple retailers' image attributes and establishing positions in customers' perceptual space.

The empirical research was designed to test three major hypotheses:

H1: There are only few image attributes of multiple retailers that are very important for customers, and play the major role in selecting a store for their shopping.

H2: A large number of image attributes can be reduced into few major factors, which reflect how customers evaluate multiple retailers.

H3: Positions of the major Lithuanian multiple retailers are clearly differentiated.

Empirical data was collected during two surveys: qualitative and quantitative.

The qualitative survey included a set of in-depth interviews with the clients of multiple retailers. These interviews were used as a pilot survey for development of a detailed questionnaire. At the same time, information from in-depth interviews was used for qualitative interpretations of some quantitative findings.

The representative quantitative survey of Lithuanian population was directly used for evaluation of image attribute importance and establishing multiple retailers' positions.

The series of in-depth interviews with clients of multiple retailers were performed during July-August of 2004, and included seventeen respondents. Respondents varied in terms of their demographic characteristics, had different income and were buying larger part of food and non-food products for their families or households. Respondents were selected from the three largest cities of Lithuania (Vilnius, Kaunas and Klaipeda).

The quantitative survey was performed in August, 2004. It was a part of the National Omnibus survey, which was run by the public opinion and market research company Baltijos tyrimai. Survey was performed in 101 areas of Lithuania, and included 1014 respondents of age from 15 to 74 . The research company ensured that the structure of the sample corresponds to the structure of Lithuanian population according to the major socio-demographic characteristics (as it was presented by the Department of Statistics of Lithuania).

Data was analyzed using SPSS 9.0 for Windows statistical data analysis program and Microsoft Excel data analysis tool. Procedures included calculation of descriptive statistics, factor analysis and development of perceptual maps with positions of multiple retailers.

\section{The main findings}

\subsection{Importance of image attributes to customers}

Analysis of data has revealed that numerous image dimensions of multiple retailers are very important to their customers. Median shows that at least ten of them 
make a significant impact when customers select a store for shopping (see Table 1).

Table 1. Multiple retailers' image attributes' importance for customers

\begin{tabular}{|c|c|c|}
\hline Image attributea & Mean & Median \\
\hline Product prices & 4,7 & 5 \\
\hline Product quality & 4,7 & 5 \\
\hline Quality of services & 4,5 & 5 \\
\hline Fast checkout & 4,5 & 5 \\
\hline Product assortment variety & 4,5 & 5 \\
\hline Long working hours & 4,5 & 5 \\
\hline Stable product assortment & 4,4 & 5 \\
\hline Store place & 4,4 & 5 \\
\hline Product layout and order & 4,3 & 5 \\
\hline $\begin{array}{l}\text { Price discounts and special } \\
\text { offers }\end{array}$ & 4,2 & 5 \\
\hline $\begin{array}{l}\text { Safety of cars and things in } \\
\text { cameras }\end{array}$ & 4,1 & 4 \\
\hline Store layout and atmosphere & 4,0 & 4 \\
\hline Parking facilities & 3,8 & 4 \\
\hline $\begin{array}{l}\text { Products of famous } \\
\text { manufacturers }\end{array}$ & 3,8 & 4 \\
\hline Store exterior & 3,8 & 4 \\
\hline Frequent shopper programs & 3,8 & 4 \\
\hline Professional security & 3,7 & 4 \\
\hline Additional services & 3,7 & 4 \\
\hline Store name and reputation & 3,6 & 4 \\
\hline $\begin{array}{l}\text { Other retailers, services and } \\
\text { catering nearby }\end{array}$ & 3,6 & 4 \\
\hline Lotteries and games & 3,4 & 4 \\
\hline References of friends & 3,3 & 3 \\
\hline Private label products & 3,3 & 3 \\
\hline Contingent of clients & 2,5 & 3 \\
\hline
\end{tabular}

These results allowed rejecting the first hypothesis (there are only few image attributes of multiple retailers that are very important for customers, and play the major role in selecting a store for their shopping). Findings showed totally opposite picture: there are many image attributes that play significant role in customers' evaluations.

In-depth interviews showed that typically customers define and evaluate from two to eight the most important image attributes. Comparing the results of both surveys, we came to the conclusion that image attributes importance mean and median analysis is not sufficient for naming the most significant image attributes, or even defining their typical number. Therefore we performed frequencies' analysis, asking respondents to directly specify three the most important image attributes (Table 2).

Table 2. Image attributes, which are the most important for multiple retailers' clients

\begin{tabular}{|c|c|}
\hline Image attributes & $\begin{array}{l}\text { Percentage of } \\
\text { customers saying that } \\
\text { this attribute is the } \\
\text { most important }\end{array}$ \\
\hline Product prices & $80,9 \%$ \\
\hline Product quality & $59,1 \%$ \\
\hline Product assortment variety & $34,4 \%$ \\
\hline Store place & $24,4 \%$ \\
\hline Quality of services & $16,8 \%$ \\
\hline Price discounts and special offers & $15,6 \%$ \\
\hline Fast checkout & $10,7 \%$ \\
\hline Stable product assortment & $8,2 \%$ \\
\hline Long working hours & $7,6 \%$ \\
\hline Product layout and order & $4,5 \%$ \\
\hline Parking facilities & $4,2 \%$ \\
\hline Safety of cars and things in cameras & $3,6 \%$ \\
\hline No answer & $3,0 \%$ \\
\hline Frequent shopper programs & $2,4 \%$ \\
\hline Additional services & $2,2 \%$ \\
\hline Lotteries and games & $2,0 \%$ \\
\hline $\begin{array}{l}\text { Other retailers, services and catering } \\
\text { nearby }\end{array}$ & $1,9 \%$ \\
\hline Store layout and atmosphere & $1,8 \%$ \\
\hline Store exterior & $1,4 \%$ \\
\hline Products of famous manufacturers & $1,2 \%$ \\
\hline References of friends & $0,9 \%$ \\
\hline Store name and reputation & $0,7 \%$ \\
\hline Private label products & $0,5 \%$ \\
\hline Professional security & $0,5 \%$ \\
\hline
\end{tabular}

Customers most frequently named product prices and their quality, though these two attributes are rarely applicable simultaneously: when customers need lower prices, they presumably agree with lower quality, and vice versa. Assortment variety is in the third place by the frequency of mentioning, and convenient place of a store is only in the fourth place. Most probably, this can be explained by increased mobility of modern buyers.

Overall results of image attributes' importance evaluation can be compared to results of similar 
market surveys. Public opinion and market research company Spinter performed a survey of Kaunas city customers in June, 2004. Results of the survey showed, that the most important criteria when they were selecting a shopping center included wide assortment of high quality products, convenient place and parking facilities (Jančys, 2004). Market research company TNS survey (performed in October, 2004) showed that even 90 percent of Lithuanian population select stores, products or services first considering product prices, but not their brands (BNS, 2004). These results allow confirming that price is the most important factor for Lithuanian buyers.

\subsection{Results of image attributes' factor analysis}

As it was observed, there is a large set of image attributes that significantly influence buyer's decisions about shopping places and presumably opinions about specific retailers. This complicates analysis of retailer's positions, since it is relevant only when the number of criteria is relatively small. Therefore the issue of grouping image attributes into some more general criteria has occurred. In our opinion, the most suitable method for such grouping is factor analysis, which allows discovering whether some broader factors (latent factors) exist.

Factor analysis of image attributes was directed to discover latent factors, which can be related to specific image attributes. If few latent factors could be identified, we would have a possibility of comprehensive evaluation of multiple retailers positions in customers' perceptual space.

Factor analysis of image attributes of multiple retailers covered several stages:

- Evaluation of data fit for factor analysis. Three methods of data fit evaluation were used: 1) evaluation of correlations among image attributes, 2) Bartlett Test of Sphericity and 3) Kaiser-Meyer-Olkin Measure of Sampling Adequacy.

- Factors derivation. Decision on a number of factors to extract was based on Latent Root criterion (or eigenvalues criterion) and Scree Test criterion.

- Factors rotation and interpretation. Factor rotation was performed using Varimax orthogonal rotation method. Large sample of respondents (1014 respondents) and large number of variables (24 image attributes) enabled selecting quite low level of significance of factor loadings, at which they were considered as significant: +/- 0,4 (Hair,
Anderson, Tatham, Black, 1998; Čekanavičius, Murauskas, 2001; Kim, Mueller, 1991).

Evaluation of data fit for factor analysis showed, that data fits for the analysis very well: 84 percent of image attributes correlations were bigger than desired level of 0,30 (Hair at al., 1998), Bartlett Test of sphericity criteria was lower than significance level, and this meant that image attributes are not independent (Čekanavičius, Murauskas, 2001). Finally, Measure of Sampling Adequacy criteria was 0,951 and this showed that data perfectly fits for factor analysis (Hair at al., 1998; Čekanavičius, Murauskas, 2001).

According to Latent Root criterion, three factors could be extracted. According to Scree test criterion, four factors could be extracted. But later stages of factor analysis have showed that the final results are the same both for three factors and four factors. Besides that, final results after extraction of three factors were more coherent and better interpreted. Therefore we believe that the right choice was to extract three factors. These three factors explained 56 percent of variation among all image attributes.

Unrotated factor matrix showed that all image attributes are linked to only one of the three factors. After applying Varimax factor rotation, the first factor was related to eleven image attributes, the second factor - to nine image attributes and the third factor - to four image attributes. Eight out of twenty-four image attributes could be linked to two factors simultaneously. This could complicate interpretation and labeling of factors. We decided to ignore those eight image attributes when interpreting factors, because the objective of factor analysis was data reduction (Hair at al., 1998). Table 3 shows, which image attributes are related to a specific factor.

Darker marked attributes were ignored in factor interpretation and labeling. Almost all ignorable image attributes have the lowest loadings and were least important in the overall evaluation. Image attributes with higher loadings are more important and have more influence for factor interpretation and labeling.

We suggest naming the first factor "Additional value and image", the second factor - "Store" and the third factor - "Products". The factor "Products" is related to image attributes, which were evaluated as the most important for customers, the factor "Store" - to attributes, which were evaluated as of medium importance for customers and the factor "Additional value and image" - to attributes, which were less important for customers.

Overall results of factor analysis allow accepting the 
second hypothesis (large number of image attributes can be reduced into few major factors, which reflect how customers evaluate multiple retailers).

Table 3. Image attributes related to three factors

\begin{tabular}{|c|c|c|}
\hline Factors & Image attributes & $\begin{array}{r}\text { Factor } \\
\text { loading }\end{array}$ \\
\hline \multirow[t]{11}{*}{ Factor 1} & Private label products & 0,726 \\
\hline & Frequent shopper programs & 0,700 \\
\hline & Store name and reputation & 0,681 \\
\hline & Contingent of clients & 0,664 \\
\hline & Additional services & 0,642 \\
\hline & Products of famous manufacturers & 0,629 \\
\hline & Lotteries and games & 0,607 \\
\hline & References of friends & 0,597 \\
\hline & $\begin{array}{l}\text { Other retailers, services and } \\
\text { catering nearby }\end{array}$ & 0,589 \\
\hline & Professional security & 0,574 \\
\hline & Long working hours & 0,430 \\
\hline \multirow[t]{9}{*}{ Factor 2} & Product layout and order & 0,762 \\
\hline & Store layout and atmosphere & 0,755 \\
\hline & Store exterior & 0,665 \\
\hline & Store place & 0,654 \\
\hline & Fast checkout & 0,642 \\
\hline & Quality of services & 0,566 \\
\hline & $\begin{array}{l}\text { Safety of cars and things in } \\
\text { cameras }\end{array}$ & 0,505 \\
\hline & Parking facilities & 0,480 \\
\hline & Price discounts and special offers & 0,447 \\
\hline \multirow[t]{4}{*}{ Factor 3} & Product assortment variety & 0,765 \\
\hline & Stable product assortment & 0,706 \\
\hline & Product quality & 0,664 \\
\hline & Product prices & 0,659 \\
\hline
\end{tabular}

\subsection{Positions of multiple retailers}

During the survey, respondents were asked to evaluate the store, in which they shop the most frequently, on every of the image attributes, using a seven point semantic differential scale. Besides that, they also evaluated image attributes for their perceived 'ideal store'. Based on respondents' answers we could identify and evaluate positions of a number of chain stores: Minima, Media, Maxima, Saulute, Iki, Pigiau grybo, Rimi, Norfa and also an ideal store. Multiple retailers' and the 'ideal store' positions were identified in three-factors customers perception space. Factor scores for every chain store and the ideal store were computed as a mean of evaluations of image attributes, which are related to a particular factor. This practical method was selected because all image attributes were measured using the same interval scale and all factor loadings were positive (Čekanavičius, Murauskas, 2001). Figure 1 shows positions of multiple retailers and ideal store.

Positions of almost all multiple retailers apeares to be very close. Norfa and Media chain stores positions are almost identical. Pigiau grybo, Saulute, Media and Norfa positions, equally as Rimi, Minima and Iki positions are very close between themselves. Therefore we can argue that positions of all chain stores are very close (stores are perceived as very similar), except Maxima chain. However, position of this chain is just a bit distant from the others.

All this shows that customers see all multiple retailers as homogeneous or even monotonous group, despite differences in names of chain stores and their ownership. This is negative situation from the standpoint of positioning, since shows that there is almost no differentiation between multiple retailers. Based on these results, the third hypothesis (positions of the major Lithuanian multiple retailers are clearly differentiated) should be rejected.

The analysis also showed that requirements for an ideal store are very high. No one existing multiple retailer is close enough to the customers' perceived ideal. Only Maxima's position is a bit closer to this ideal in terms of additional value and image. This can suggest that it is almost impossible to successfully satisfy needs and requirement of all buyers. They are heterogeneous: one customer may need low prices, another high quality, third perfect services, etc. Therefore multiple retailers need to find a proper basis for effective segmentation, which would help identifying target segment(s) and satisfying its requirements properly.

Linking results of multiple retailers' position analysis with customers perceived value concept, we conclude that multiple retailers do not fully use possibilities of image development. We propose that multiple retailers' services include almost no image value, and that retailers are investing money, time and efforts only into products, services and personnel. Of course, they do it well enough, and therefore customers evaluate positions above average. But the problem is that all multiple retailers do it in a similar way and there is no differentiation among them from the standpoint of customers. 


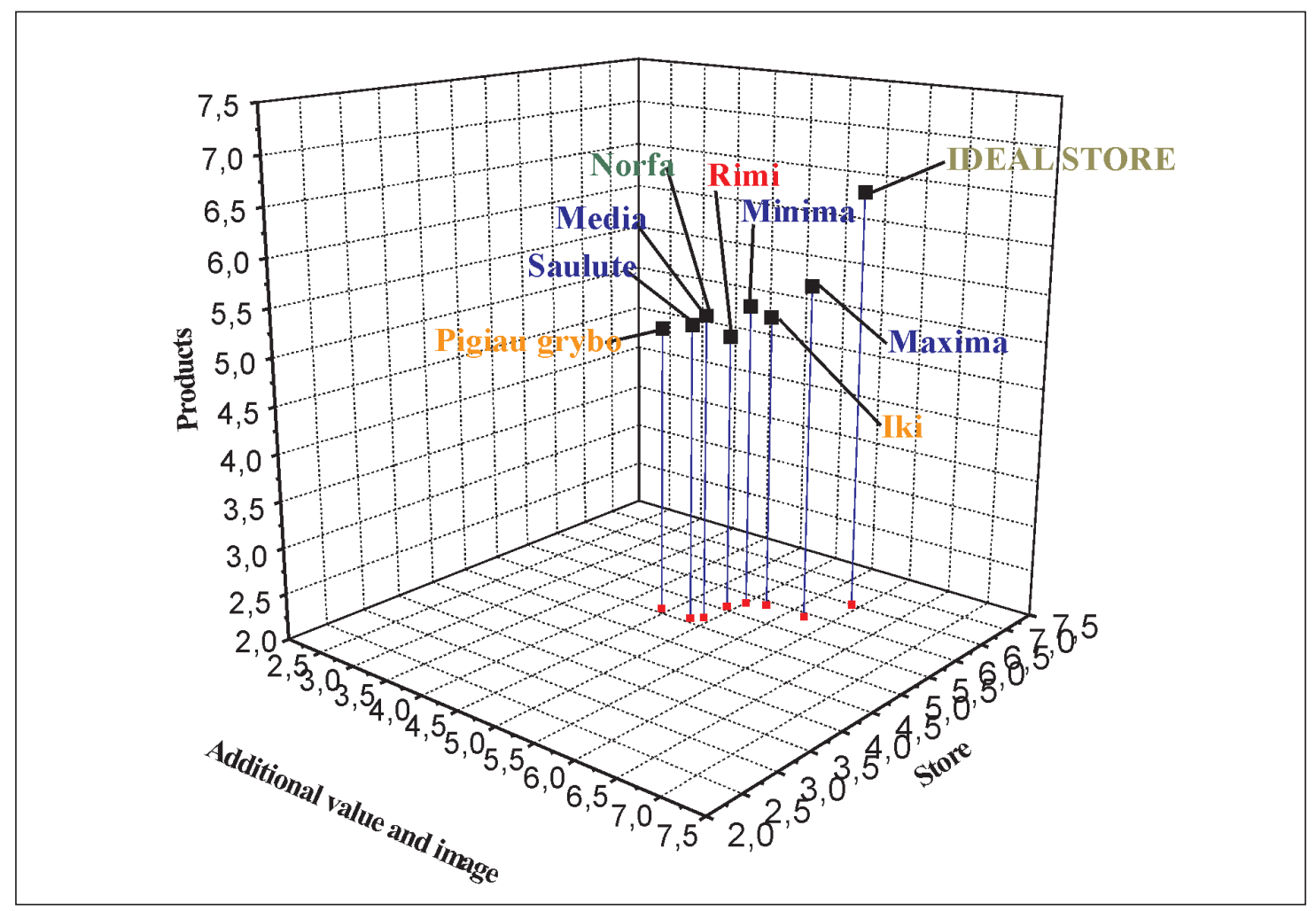

Fig 1. Positions of multiple retailers in three-factors customers' perceptual space

\section{Conclusions and implications for further research}

Buyers indicated a number of image attributes of multiple retailers, which are important for them and make impact on store selection. Some image attributes are most important than others, and they include product prices, product quality, product assortment variety and place of a store. However, the overall number of important attributes is relatively large.

There are three latent factors that integrate multiple retailers' image attributes and explain interrelationships among them. These factors are: 1) additional value and image, 2) store, and $3)$ products. These factors aggregate numerous attributes of multiple retailers, and allow comparing positions of the chain stores.

Analysis shows that there are almost no differentiation among Lithuanian multiple retailers, and customers perceive all chain stores as being very similar. This is the result of attempt to fit and serve all clients simultaneously, which is followed by lack of proper segmentation and targeting.

Managers of multiple retailers should pay more attention to image and positions of their chain stores. They should also review segmentation and targeting of multiple retailers' clients for better understanding their needs and requirements. This would be useful for finding new differentiation opportunities.

There are also some implications for further research. We suppose that it would be useful to see the dynamics of multiple retailers' image attributes and positions over time. This would help understanding how customer attitudes are changing. Besides that, it would enable re-evaluating multiple retailers' positions in customers' perceptual space when some new chain stores - Leader Price and Supernetto - has entered the market and after Minima name was changed into Mini Maxima and Hyper Rimi into Rimi Hypermarket.

\section{References}

Bell, R. (2002) Competition issues in European grocery retailing. European Retail Digest, Issue 39, p. 27-37.

Berman, B.; Evans, J. R. (2001) Retail Management. A Strategic Approach. Eight Edition. New Jersey: Prentice Hall, Inc., 708 p.

Birtwistle, G.; Clarke, I.; Freathy P. (1998) Customer decision making in fasion retailing: a segmentation analysis. International Journal of Retail \& Distribution Management, Vol. 26, No. 4, p. 147-154.

Bloemer, J.; De Ruyter, K. (1998) On the relationship between store image, store satisfaction and store loyalty. Europen Journal of Marketing, Vol. 32, No. 5/6, p. 499513. 
BNS. Prekès ženklą lietuviai keičia ì mažesnę kainą (interactive). Reviewed 15November, 2004. Access through the Internet: http://www.delfi.lt/archive/ index.php?id=5476188.

Čekanavičius, V.; Murauskas, G. (2001) Statistika ir jos taikymai. II dalis. Vilnius: TEV, 268 p. (In Lithuanian).

Darling, J. R. (2001) Successful competitive positioning: the key for entry in to the European consumer market. European Business Review, Vol. 13, No. 4, p. 209-220.

Dennis, Ch.; Murphy, J.; Marsland, D.; Cockett, T.; Patel, T. (2002) Measuring image: shopping centre case studies. The International Review of Retail, Distribution and Consumer Research, 12:4, p. 355-373.

Fernie, J.; Fernie, S.; Moore, Ch. (2003) Principles of Retailing. Oxford: Butterworth-Heinemann, 382 p.

Garton, P. A. (1995) Store loyal? A view of "differential congruence". International Journal of Retail and Distribution Management, Vol. 23, No. 12, p. 29-35.

Hair, J. F.; Anderson, R. E.; Tatham, R. L.; Black, W. C. (1998) Multivariate data analysis. Fifth edition. New Jersey: Prentice-Hall, Inc., 730 p.

Jančys A. Statistikos veidrodyje - kauniečio vartotojo portretas. (2004 08 27). Laikinoji sostine, Lietuvos rytas, p. 4.

Joyce, M. L.; Lambert, D. R. (1996) Memories of the way stores were and retail store image. International Journal of Retail \& Distribution Management, Vol. 24, No. 1, p. 24-33.

Kim, J.-O.; Mueller, Ch. W. (1991) Introduction to factor analysis. What it is and how to do it. Sage University Papers series on Quantitative Applications in the Social Sciences, 07-013. Beverly Hills and London: Sage Publications, Inc., 79 p.

Kotler, P. (2003) Marketing management. Eleventh edition. New Jersey: Pearson Education, Inc., 706 p.

McGoldrick, P. J.; Ho, S. S. L. (1992) International positioning: Japanese department stores in Hong Kong. European Journal of Marketing, Vol. 26, No. 8/9, p. 6173.

Mitchel, V. W. (1998) A role for consumer risk perceptions in grocery retailing. British Food Journal, 100/4, p. 171183.
Mitchell, V. W, Kiral, R. H. (1998) Primary and secondary store-loyal customer perceptions of grocery retailers. British Food Journal, 100/7, p. 312-319.

Newman, A. J.; Cullen, P. (2001) From retail theatre to retail food show. The shrinking face of grocery. British Food Journal, Vol. 103, No. 7, p. 443-452.

Omar, O. (1999) Retail Marketing. London: Financial Times \& Pitman Publishing, $448 \mathrm{p}$.

Porter, S. S.; Claycomb, C. (1997) The influence of brand recognition on retail store image. Journal of Product \& Brand Management, Vol. 6, No. 6, p. 373-387.

Ries, A.; Trout, J. (1986) Positioning: the Battle for Your Mind. New York: McGraw-Hill, 213 p.

Rudolph, T.; Becker, K. (2002) Efficient differentiation: a systematic approach for retailers to appear unique. European Retail Digest, Issue 38, p. 1-6.

Ruiz, F. J. M. (1999) Image of suburban shopping malls and two-stage versus uni-equational modelling of the retail trade attraction. European Journal of Marketing, Vol. 33, No. 5/6, p. 512-530.

Samli, A. C. (1998) Strategic marketing for success in retailing. Westport: Quorum Books, 387 p.

Sheinin, D. A.; Wagner, J. (2003) Pricing store brands across categories and retailers. Journal of Product \& Brand Management, Vol. 12, No. 4, p. 201-219.

Sit, J.; Merrilees, B.; Birch, D. (2003) Entertainment seeking shopping centre patrons: the missing segments. International Journal of Retail and Distribution Management, Vol. 31, No. 2, p. 80-94.

Sullivan, M.; Adcock, D. (2002) Retail Marketing. London: Thompson, $350 \mathrm{p}$.

Taylor, S. L.; Cosenza, R. M. (2002) Profiling later aged female teens: mall shopping behaviour and clothing choice. Journal of Consumer Marketing, Vol. 19, No. 5, p. 393-408.

Thompson,K. E; Chen, Y. L. (1998) Retail store image: a means-end approach. Journal of Marketing Practice: Applied Marketing Science, Vol. 4, No. 6, p. 161-173.

Uusitalo, O. (2001) Consumer perceptions of grocery retail formats and brands. International Journal of Retail \& Distribution Management, Vol. 29, No. 5, p. 214-225. 